\title{
UNA NUEVA ATRIBUCIÓN AL ESCULTOR BENITO DE HITA Y CASTILLO: EL CRISTO DE LA HUMILDAD Y PACIENCIA DE LA CAMPANA
}

\section{A NEW ATTRIBUTION TO THE SCULPTOR BENITO DE HITA Y CASTILLO: THE CHRIST OF THE HUMILITY AND PATIENCE OF LA CAMPANA}

\author{
José RodA PeÑa \\ Universidad de Sevilla. España \\ roda@us.es
}

En la iglesia del extinguido convento franciscano de La Campana, municipio situado en la comarca sevillana de la Campiña, se conserva una escultura policromada de un Cristo de la Humildad y Paciencia que atribuimos al escultor Benito de Hita y Castillo (1714-1784), una de las personalidades más destacadas de la plástica barroca hispalense del siglo XVIII.

Palabras claves: Benito de Hita y Castillo; Cristo de la Humildad y Paciencia; La Campana; escultura sevillana; siglo XVIII.

The Church of the extinguished franciscan Convent of La Campana, town located in the Sevillian region of the Campiña, preserves a polychrome sculpture of a Christ of Humility and Patience that we attribute to the sculptor Benito de Hita y Castillo (1714-1784), one of the most prominent personalities of the local Baroque plastic in the $18^{\text {th }}$ century.

Keywords: Benito de Hita y Castillo; Christ of Humility and Patience; La Campana; Sevillian sculpture; $18^{\text {th }}$ century.

En la recién rehabilitada iglesia de San Sebastián, perteneciente al exclaustrado convento franciscano situado en las afueras de la villa de La Campana ${ }^{1}$,

${ }^{1}$ Los franciscanos se instalaron en La Campana en 1644, tras haber obtenido la preceptiva licencia otorgada por el arzobispo de Sevilla don Gaspar de Borja y Velasco el 14 de diciembre de dicho año. El convento, perteneciente a la provincia de los Ángeles de la 
en la campiña de Sevilla, está expuesta al culto una escultura en madera policromada de un Cristo de la Humildad y Paciencia que, a pesar de su apreciable calidad artística, apenas ha merecido alguna mínima mención por parte de la historiografía especializada. Así, los autores del Catálogo arqueológico y artístico de la provincia de Sevilla se limitaron en 1943 a registrar su presencia en el retablo mayor del templo², como efectivamente puede comprobarse por una fotografía tomada por José María González-Nandín y Paúl el 30 de diciembre de 1939, conservada entre los fondos de la Fototeca de la Universidad de Sevilla ${ }^{3}$, donde la efigie se cobija en la hornacina central del cuerpo principal del referido altar. En el Inventario artístico de Sevilla y su provincia de 1982 ya aparece reubicada esta escultura -se dice que provisionalmente- en la nave de la iglesia de San Sebastián y se indica su medida aproximada, 1,20 m de alto - en realidad, 1,25-, que en razón de su actitud sedente, puede ser considerada de tamaño natural ${ }^{4}$. Los historiadores del arte García Rodríguez y González Isidoro, en 1983, fueron los primeros en proponer una catalogación para esta talla, considerándola como una obra anónima sevillana fechable a finales del siglo XVIII ${ }^{5}$.

Se carece, por el momento, de toda información referida a qué persona o institución pudiera haber encargado esta imagen del Cristo de la Humildad y Paciencia y a la fecha concreta en que ello se produjo, pero sí es importante recalcar que ha sido en época relativamente cercana cuando adquirió una función procesional -sumada a la de culto interno-, al convertirse en titular de una cofradía de penitencia, fundada a finales del siglo XIX o comienzos del XX, que desfila por las calles de La Campana en la noche del Miércoles Santo, viéndose acompañada

orden de San Francisco, se dedicó oficialmente a San Antonio de Padua, pero la población siempre se refirió a dicho cenobio bajo el nombre de San Francisco o de San Sebastián, por ubicarse parte de su iglesia sobre el solar de una vieja ermita de esta última advocación. Cfr. MIRA CABALLOS, Esteban: La Campana. Noticias históricas. Sevilla, 1998, pp. 7678. La iglesia de San Sebastián quedó reabierta al culto en 2007, tras su pertinente restauración, quedando pendiente la recuperación de las restantes dependencias conventuales.

${ }^{2}$ HERNÁNDEZ DÍAZ, José; SANCHO CORBACHO, Antonio y COLLANTES DE TERÁN, Francisco: Catálogo arqueológico y artístico de la provincia de Sevilla. T. II. Sevilla, 1943, p. 35. Para el profesor Francisco Javier Herrera, este retablo mayor debió de construirse en el segundo cuarto del siglo XVIII, pero su aspecto actual responde a una profunda transformación operada a finales de dicha centuria o durante el XIX, que lo despojó de su talla original, procediéndose además a su jaspeado. HALCÓN, Fátima; HERRERA, Francisco y RECIO, Álvaro: El retablo barroco sevillano. Sevilla, 2000, p. 398.

${ }^{3}$ Su número de registro es el 3-4620.

${ }^{4}$ AA.VV.: Inventario artístico de Sevilla y su provincia. T. I. Madrid, 1982, p. 104.

${ }^{5}$ GARCÍA RODRÍGUEZ, Antonio y GONZÁLEZ ISIDORO, José: Las imágenes titulares de la cofradía carmonense de la Humildad y Paciencia. Contribución al estudio de la escultura sevillana del siglo dieciocho. Carmona, 1983, p. 53. 
en su mismo paso por una dieciochesca Virgen de los Dolores, de candelero para vestir, que es propiedad de la parroquia de Santa María la Blanca ${ }^{6}$.

Respecto a la historia material del Cristo solo se le conocen dos intervenciones, ambas muy próximas en el tiempo: la primera fue llevada a cabo en 2006 por Seo Restauro, una empresa con sede en Lucena (Córdoba), dirigida por las licenciadas en Bellas Artes María Santamaría Román y Carmen Gallardo Pérez; la segunda, entre el 20 de septiembre de 2013 y el 2 de abril de 2014, corrió a cargo del prestigioso restaurador sevillano Enrique Gutiérrez Carrasquilla, cuyo proceso tuve la oportunidad de seguir, brindándome la ocasión de examinar la efigie con detenimiento $^{7} \mathrm{y}$ de formular, ahora, su atribución fundamentada al escultor Benito de Hita y Castillo (1714-1784) ${ }^{8}$.

Se representa en esta escultura a Jesús que, una vez llegado al Gólgota, y tras haber sido despojado de su túnica, espera pacientemente el momento de ser crucificado, mostrándose prácticamente desnudo, pues solo sus caderas quedan envueltas por un amplio paño de pureza, surcado por un abanico de amplios y profundos pliegues. Sentado sobre un sillar cuadrangular de apariencia marmorizada -de gran variedad cromática, con una base de panes de oro en determinadas zonas-, reclina su cabeza en la palma de la mano izquierda con gesto apesadumbrado, apoyando el codo sobre el muslo, mientras que la derecha se deja caer de manera laxa, reposando el antebrazo en la pierna correspondiente. Al encorvar el torso, las vértebras de su columna quedan nítidamente señaladas

${ }^{6}$ DELGADO ABOZA, Francisco Manuel: "Hermandad del Santísimo Cristo de la Humildad y Paciencia y Nuestra Señora de los Dolores", en Misterios de Sevilla. T. III. Sevilla, 1999, pp. 237-241. La imagen mariana fue restaurada en 2011 por el veterano escultor y pintor José Pérez Conde, nacido en Alosno (Huelva) el 15 de junio de 1937.

${ }^{7}$ La restauración de Gutiérrez Carrasquilla consistió, básicamente, en la fijación de la policromía y la retirada de los repintes que la escultura presentaba en todo el sudario y en amplias zonas del rostro, brazos y piernas; el estucado y reintegración cromática de las lagunas de la superficie pictórica; el resanado del soporte lignario; la incorporación de una peana cuadrangular abrazando la base original de la imagen, a fin de procurarle una mayor estabilidad y de facilitar su transporte; la introducción de cajillos metálicos en la cabeza para encajar en ellos las potencias, y la protección final. Agradezco a mi buen amigo Enrique Gutiérrez Carrasquilla la información facilitada al respecto y las fotografías del Cristo que ilustran este artículo.

${ }^{8}$ Sigue siendo de obligada consulta la única monografía dedicada a este escultor por parte de GONZÁLEZ ISIDORO, José: Benito de Hita y Castillo (1714-1784). Escultor de las Hermandades de Sevilla. Sevilla, 1986. En 2014 revisé las principales aportaciones historiográficas que se habían vertido durante los últimos veinticinco años sobre tan destacada figura del barroco dieciochesco sevillano, al tiempo que di a conocer un significativo elenco de imágenes que podían atribuírsele con seguridad. RODA PEÑA, José: "Nuevas atribuciones al escultor Benito de Hita y Castillo en el tercer centenario de su nacimiento (1714-2014)”, Laboratorio de Arte, 26, 2014, pp. 163-184. 
en la espalda. Puede decirse que su complexión anatómica es fuerte, pero no excesivamente musculada. La policromía de la imagen, que por fortuna es la original, nos muestra a base de veladuras rojizas, violáceas y verdes una amplia y naturalista cartografía de magulladuras, contusiones y huellas de latigazos de las que se desprenden finos regueros de sangre, con especial prolijidad en la espalda, mientras que la visión frontal de la efigie queda bastante más limpia de heridas. Los pies descansan sobre una superficie pedregosa, elevándose el izquierdo sobre un pequeño promontorio de rocas, un recurso que contribuye a dinamizar la composición de la figura, al crear entre ambas extremidades inferiores dos diagonales paralelas y a distinta altura. Es este, por consiguiente, un momento de reflexión y de oración íntima protagonizado por Cristo en el Calvario, logrando conmover al espectador con la resignada y compungida expresión de su rostro. La bóveda craneal se presenta completamente lisa, pues desde su origen se concibió para lucir una cabellera de pelo natural -todo un signo de identidad barroca-, como sigue sucediendo hasta hoy, superponiéndole una corona de espinas y despuntando sobre la testa tres potencias metálicas. Otro elemento ornamental y simbólico que a veces exhibe, incluso en su anual salida procesional, es el dogal o cordón de hilo de oro que pende de su cuello y que, ajustado por un pasador, cae rodeando la muñeca derecha, al tiempo que el otro cabo desciende desde la pierna opuesta, rematándose en sendas borlas de pasamanería.

Deberá recordarse brevemente que este modelo iconográfico del Cristo de la Humildad y Paciencia surge a finales del siglo XIV en el arte centroeuropeo, como producto de la mística bajomedieval, sin reflejo en los textos canónicos 9 . Suele enmarcarse, como es el caso que nos ocupa, en el ciclo pasionista de los preparativos de la Crucifixión, aunque menudean los ejemplos, tanto en pintura como en escultura, en que la figura sedente y silente de Jesús aparece junto a la columna de la Flagelación, tras haber recibido los azotes, de manera que el suceso se traslada desde el Calvario hasta el Pretorio. Sea como fuere, tan conmovedora escena adquirió carta de naturaleza por toda Europa a raíz de que Alberto Durero la utilizara como frontispicio de la colección de grabados que publicó en 1511 bajo el título de la Pequeña Pasión; en efecto, dicha xilografía recoge tal iconografía en clave alegórica, puesto que los pies de Cristo horadados por los clavos de la cruz lo identifican como Varón de Dolores, encarnación de la Pasión perpetua. También queremos señalar que el motivo de la cabeza apoyada sobre la mano deriva de una tradición pictórica milenaria, que ya aparece en los dolientes de los sarcófagos egipcios. Evidentemente, es un signo de dolor, pero también puede significar fatiga y meditación. Además, no puede olvidarse que así se plasmó artísticamente durante siglos el temperamento melancólico o saturnino, al punto de que a este Jesús pensieroso cabría interpretarlo como una suerte de

${ }^{9}$ MÂLE, Émile: L'Art religieux de la fin du Moyen-âge en France. París, 1908, p. 94. Del mismo autor, L'Art religieux du XIIe au XVIIIe siécle. París, 1961, pp. 105-106. 
cristianización del dios Saturno, con todas sus implicaciones herméticas en relación con el mundo de la alquimia ${ }^{10}$.

La inclusión de este Cristo de la Humildad y Paciencia en el catálogo de las obras firmemente atribuidas a Benito de Hita y Castillo responde a razones de índole estilística, dado que, por el momento, no se ha localizado ninguna fuente documental que pueda refrendar dicha asignación de modo fehaciente. Es importante recordar que a Hita y Castillo ya lo encontramos trabajando en La Campana, para su iglesia parroquial de Santa María la Blanca, desde un momento bastante temprano de su trayectoria profesional, tallando en torno a 1743 el repertorio escultórico del retablo de la Virgen del Rosario - menos su imagen titular de candelero, existente con anterioridad-, al que debe añadirse la Inmaculada Concepción, fechable unos veinticinco años después, que preside el altar rococó, frontero al anterior, en el brazo del crucero del templo ${ }^{11}$. Creo que entre uno y otro compromiso laboral, esto es, en la década de 1750 , podría situarse provisionalmente la ejecución del Cristo de la Humildad y Paciencia, teniendo en cuenta que en 1749 se celebraron las fiestas por la conclusión "del templo nuevo fabricado en dicho convento" -refiriéndose a la iglesia de San Sebastián- ${ }^{12}$, y que de inmediato se inició su amueblamiento litúrgico y, según puede presumirse, la acogida entre sus muros y capillas de nuevas devociones como esta ${ }^{13}$.

La atenta contemplación del rostro del Cristo de la Humildad y Paciencia de La Campana nos remite indefectiblemente a un tipo masculino habitualmente empleado por Benito de Hita y Castillo en otras creaciones suyas de temática pasionista, donde se repiten determinados rictus expresivos causados por la tensión emocional y los padecimientos físicos. Es lo que sucede con el trazado sinuoso de sus cejas fruncidas por la tristeza y el dolor, la caída de los párpados que hace entornar la enternecedora mirada de los ojos vítreos o la sentimental congoja que emana de los labios entreabiertos, rasgos faciales y de carácter que comparte muy claramente con el Jesús de la Caída de la iglesia de San Francisco de Santa Cruz

${ }^{10}$ KLIBANSKY, Raymond; PANOFSKY, Erwin y SAXL, Fritz: Saturno y la melancolía. Madrid, 1991, pp. 281-282; MARTÍNEZ DE LA PEÑA, Domingo: "Iconografía cristiana y alquimia: el Señor de la Humildad y Paciencia”, en Homenaje a Alfonso Trujillo. Tenerife, 1982, pp. 581-597; y SÁNCHEZ LÓPEZ, Juan Antonio: El alma de la madera. Cinco siglos de iconografía y escultura procesional en Málaga. Málaga, 1996, pp. 195-197.

${ }^{11}$ RODA PEÑA, José: "Esculturas de Benito de Hita y Castillo en la parroquia de La Campana (Sevilla)", Laboratorio de Arte, 27, 2015, pp. 265-279.

${ }^{12}$ HERNÁNDEZ DÍAZ, J.; SANCHO CORBACHO, A. y COLLANTES DE TERÁN, F.: Catálogo arqueológico y artístico..., op. cit., p. 45.

${ }_{13}$ Por ejemplo, el retablo situado en el brazo de la epístola del crucero contiene una inscripción donde se indica que fue dorado en 1753. AA.VV.: Inventario artístico de Sevilla y su provincia, op. cit., p. 103. 
de La Palma -firmado y fechado por Hita en $1752-{ }^{14}$ y con los atribuidos Flagelados de las parroquias de Santa María de la Mesa de Utrera (c. 1760) ${ }^{15}$ y Santiago el Mayor de Hinojos ${ }^{16}$, esculturas todas ellas de tamaño natural y ligadas actualmente a cofradías que las sacan en procesión durante la Semana Santa. La configuración del bigote y de la barba resulta bastante similar en los cuatro Cristos que acabamos de mencionar, a base de hebras capilares finas y ondulantes de talla superficial, resolviéndose bajo el mentón en dos gruesos mechones de recorrido curvilíneo, convergentes en el centro y con una leve separación entre las puntas, que resulta más visible y acusada en el caso del Caído de Santa Cruz de La Palma.

No terminan aquí las similitudes que a nivel técnico y morfológico pueden rastrearse entre este cuádruple grupo de imágenes que representan a Cristo en tres momentos diferentes de su Pasión, que estamos utilizando en términos comparativos para cimentar la atribución de una de ellas, la conservada en el pueblo sevillano de La Campana, a la gubia de Benito de Hita y Castillo. Es el caso del doble pliegue abdominal que aparece detallado con total precisión en las tres esculturas que presentan su pecho desnudo e inclinado: el Cristo de la Humildad y Paciencia de La Campana y los Atados a la Columna de Hinojos y Utrera. Por otra parte, el gesto relajado de la mano derecha del Señor de la Humildad, con el pulgar retrasado, el índice casi extendido y en progresivo repliegue los dedos corazón y, sobre todo, anular y meñique, que aparecen con sus falanges muy flexionadas, lo encontramos casi calcado -si acaso con un grado de tensión algo mayor-, al igual que su epidérmico mapa de venas dorsales, en la mano derecha del Cristo a la Columna de Utrera y en la izquierda del de Hinojos. En la peculiar tipología de los pies que suele tallar Hita y Castillo, con su estructura ósea y muscular muy marcada, así como con la palmaria definición de las arterias que los irrigan, encontramos otro elemento identificativo de su quehacer plástico; el alargado dedo gordo, por más señas, suele mostrar una pronunciada desviación hacia el exterior de la línea curva que se forma junto a la articulación de su base, forzando su separación respecto al segundo, que alguna vez lo supera en longitud para conformar lo que se denomina un pie "griego", mientras que los restantes dedos aparecen más pegados entre sí, según se comprueba en los simulacros de La Campana e Hinojos. A estas mismas características responden los pies del San Juan Evangelista de la Hermandad de la Amargura de Sevilla (c. 1760), de una factura especialmente bien cuidada.

${ }^{14}$ HERNÁNDEZ PERERA, Jesús: "Un Cristo de Hita y Castillo en Santa Cruz de La Palma", Archivo Español de Arte, 122, 1958, pp. 146-148.

${ }^{15}$ QUILES GARCÍA, Fernando: "Una nueva obra de Julián Jiménez y de Benito de Hita y Castillo”, Boletín de Arte, 11, 1990, pp. 153-158.

${ }_{16}$ RODA PEÑA, J.: "Nuevas atribuciones al escultor Benito de Hita y Castillo...", op. cit., pp. 172-177. 
En conclusión, este Cristo de la Humildad y Paciencia, venerado en la iglesia de San Sebastián de La Campana, puede considerarse una significativa aportación a la nómina de esculturas que se adjudican al escultor Benito de Hita y Castillo, y la única de esta iconografía que por ahora figuraría en su catálogo razonado. Se trata, sin duda, de un importante eslabón en esa soberbia cadena de interpretaciones que la plástica escultórica sevillana nos ha legado -y sigue cultivando aún en nuestros días- de esta figura semidesnuda de Cristo que espera, humilde y pacientemente sentado, el momento de su crucifixión, desde aquellos pioneros ejemplares anónimos en papelón y telas encoladas de finales del siglo XVI o comienzos del XVII que se conservan en la iglesias hispalenses de los hospitales de Nuestra Señora de la Paz y del Santísimo Cristo de los Dolores (Pozo Santo) y en la del exconvento de los Terceros, pasando por las efigies barrocas realizadas por Francisco de Villegas (1622, iglesia de la Santísima Trinidad de Jerez de la Frontera), Jacinto Pimentel (1638, parroquia de San Agustín de Cádiz), Pedro Roldán (atrib., c. 1667, parroquia de la Encarnación de Constantina), Antonio de Quirós (atrib., 1696, colegial del Divino Salvador de Sevilla) y José Montes de Oca (atrib., parroquia de Santo Domingo de Guzmán de Bornos), hasta llegar a las más recientes versiones de Antonio Castillo Lastrucci (1941, parroquia de la Asunción de Mairena del Alcor; 1942, iglesia de la Inmaculada Concepción de Sierra de Yeguas), Juan Abascal Fuentes (1981, capilla de Nuestra Señora de la Aurora de Lebrija) o Manuel Ramos Corona (2007, parroquia de San Vicente de Paúl de Málaga), entre tantas otras que podríamos traer a colación.

Fecha de recepción: 24 de septiembre de 2016

Fecha de aceptación: 4 de enero de 2017 


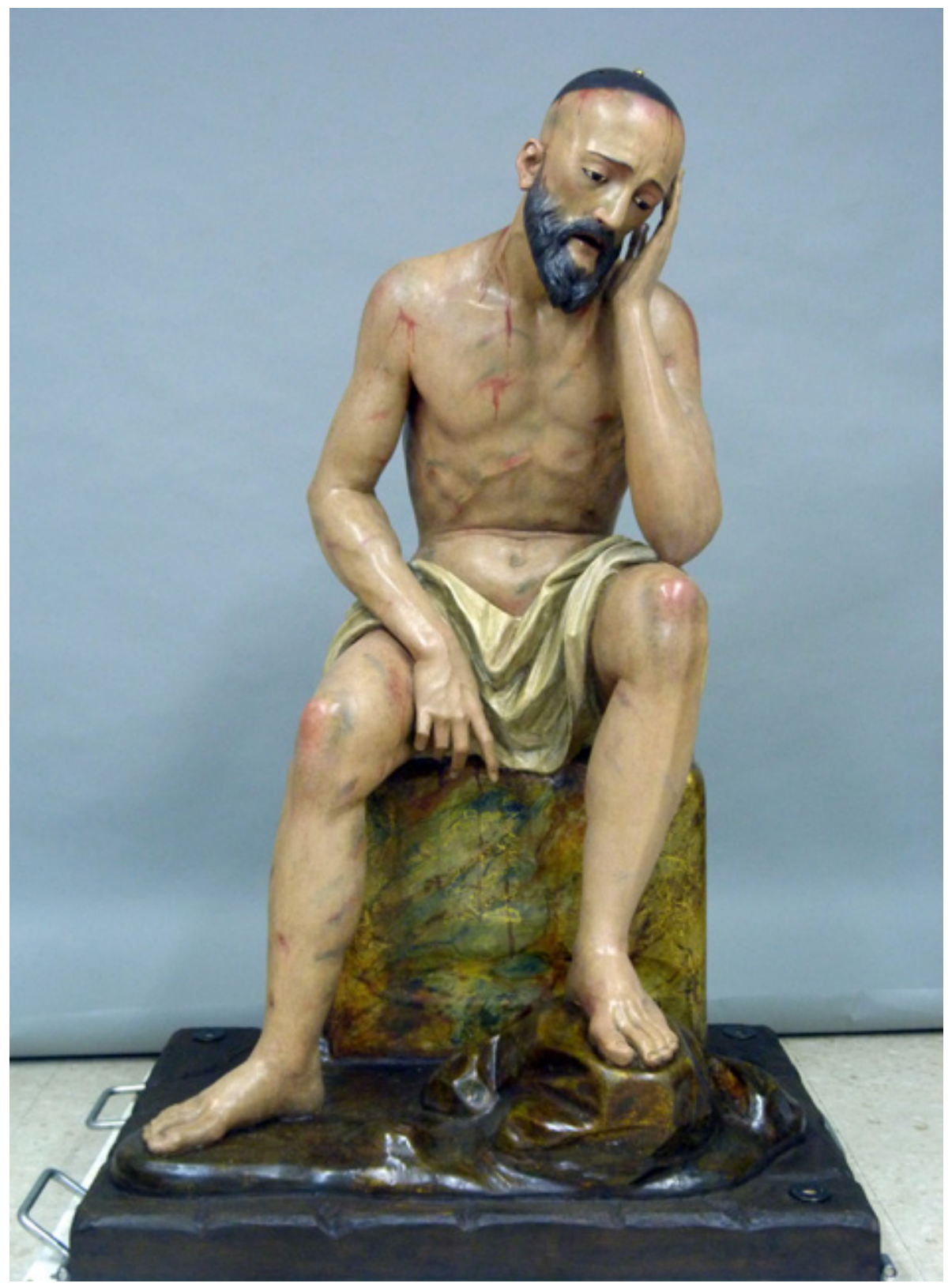

Figura 1. Benito de Hita y Castillo, Cristo de la Humildad y Paciencia, década de 1750, iglesia de San Sebastián del exconvento de San Francisco, La Campana (Sevilla). 


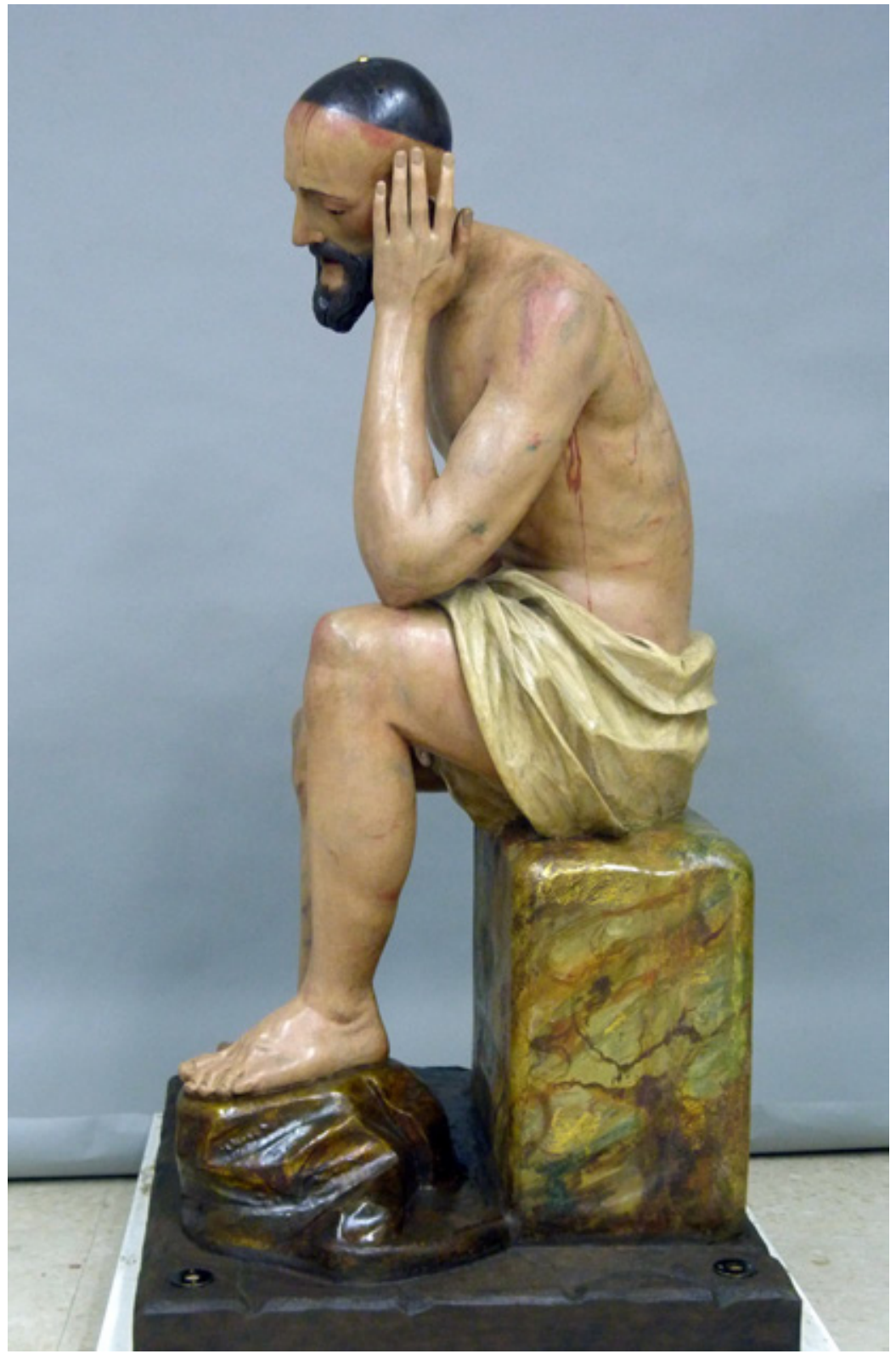

Figura 2. Benito de Hita y Castillo, Cristo de la Humildad y Paciencia (lateral izquierdo). 


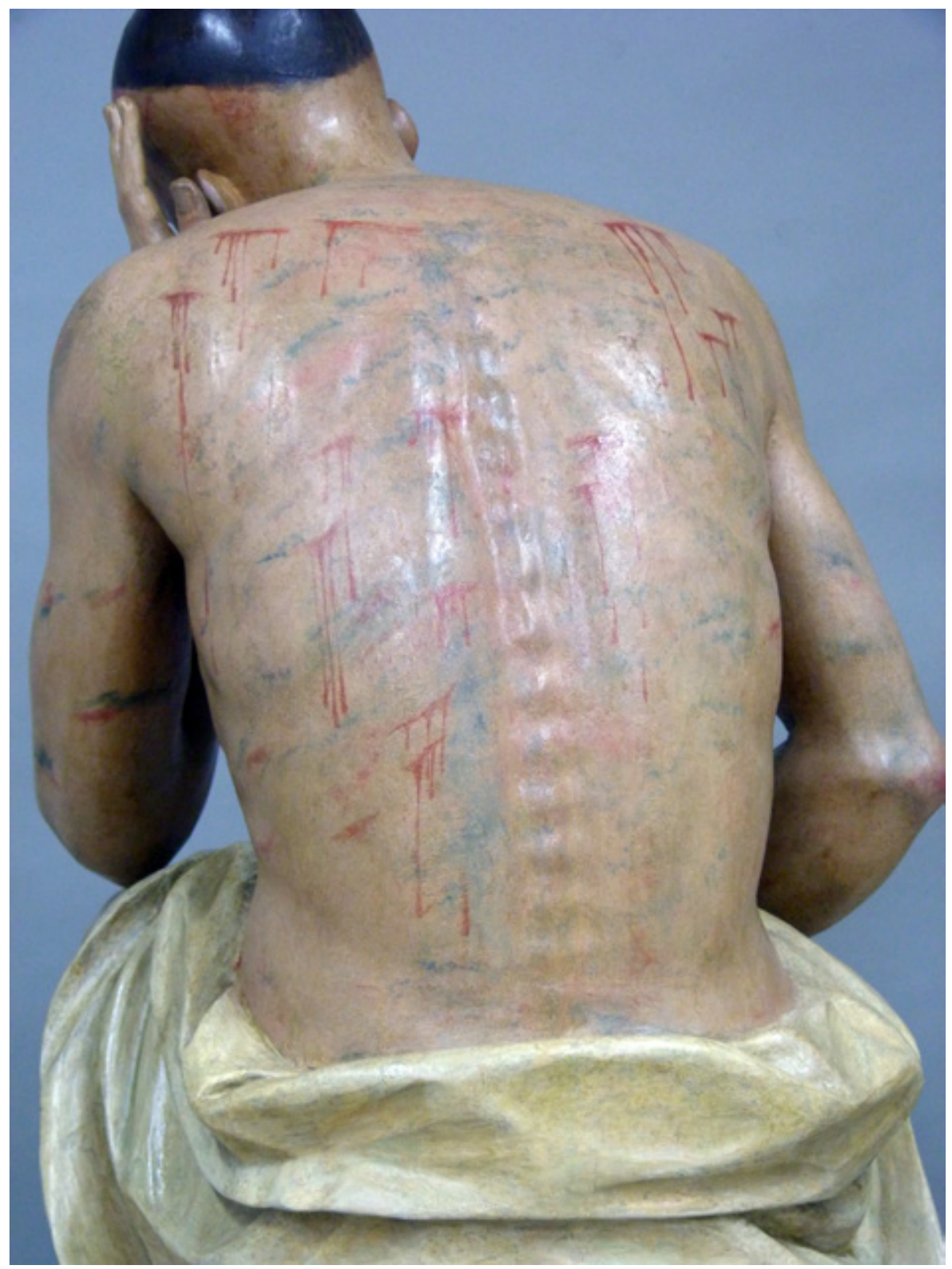

Figura 3. Benito de Hita y Castillo, Cristo de la Humildad y Paciencia (detalle de la espalda). 


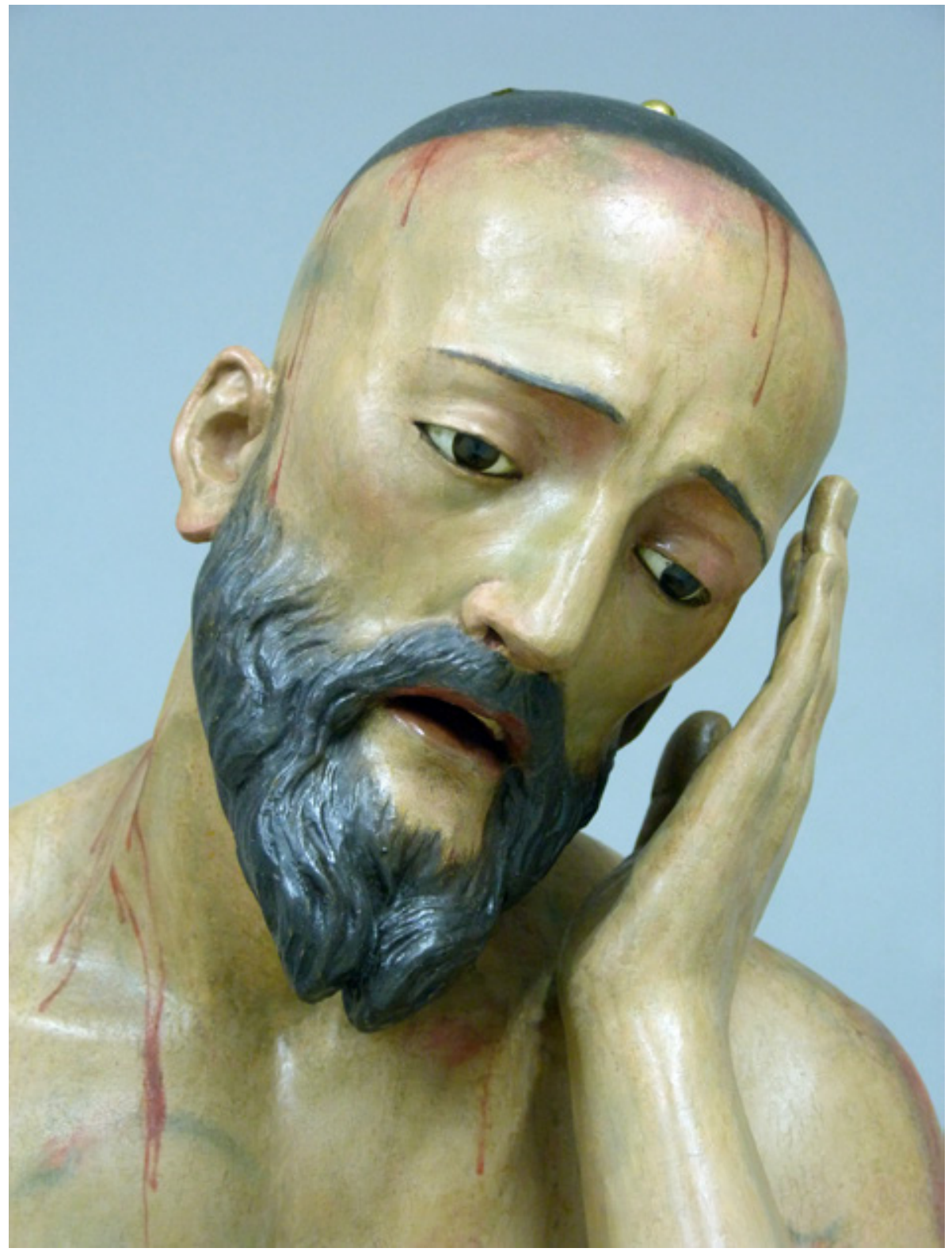

Figura 4. Benito de Hita y Castillo, Cristo de la Humildad y Paciencia (detalle de la cabeza). 


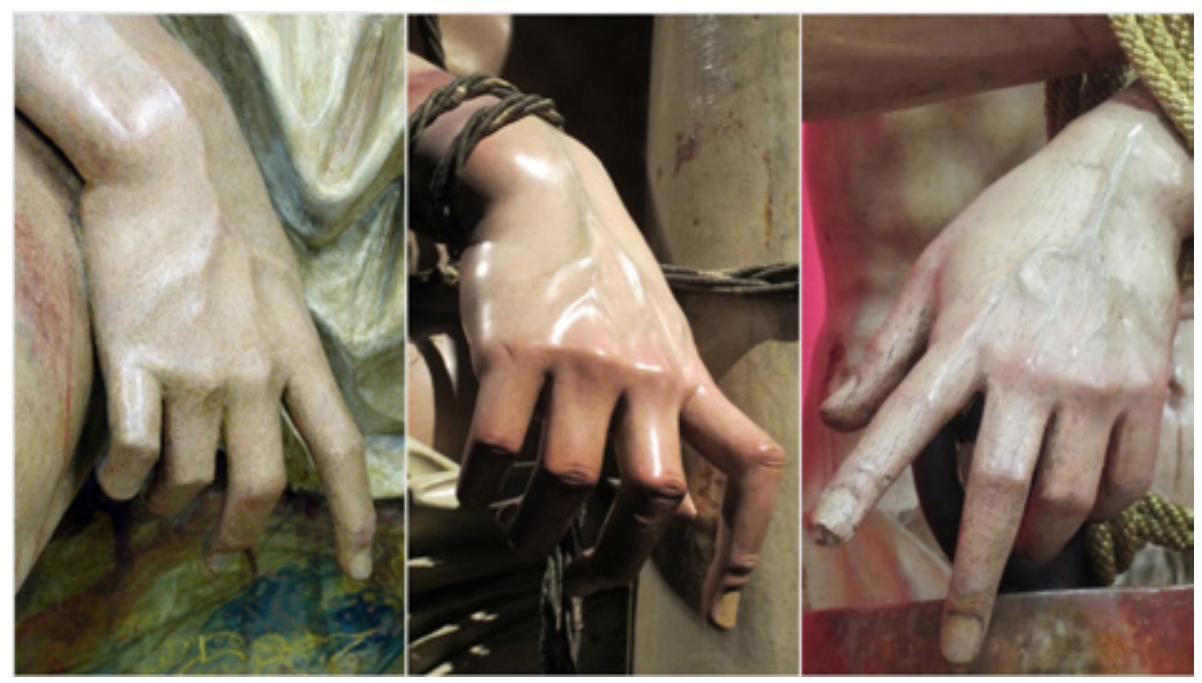

Figura 5. Benito de Hita y Castillo, Manos del Cristo de la Humildad y Paciencia de La Campana y de los Atados a la Columna de Utrera e Hinojos.

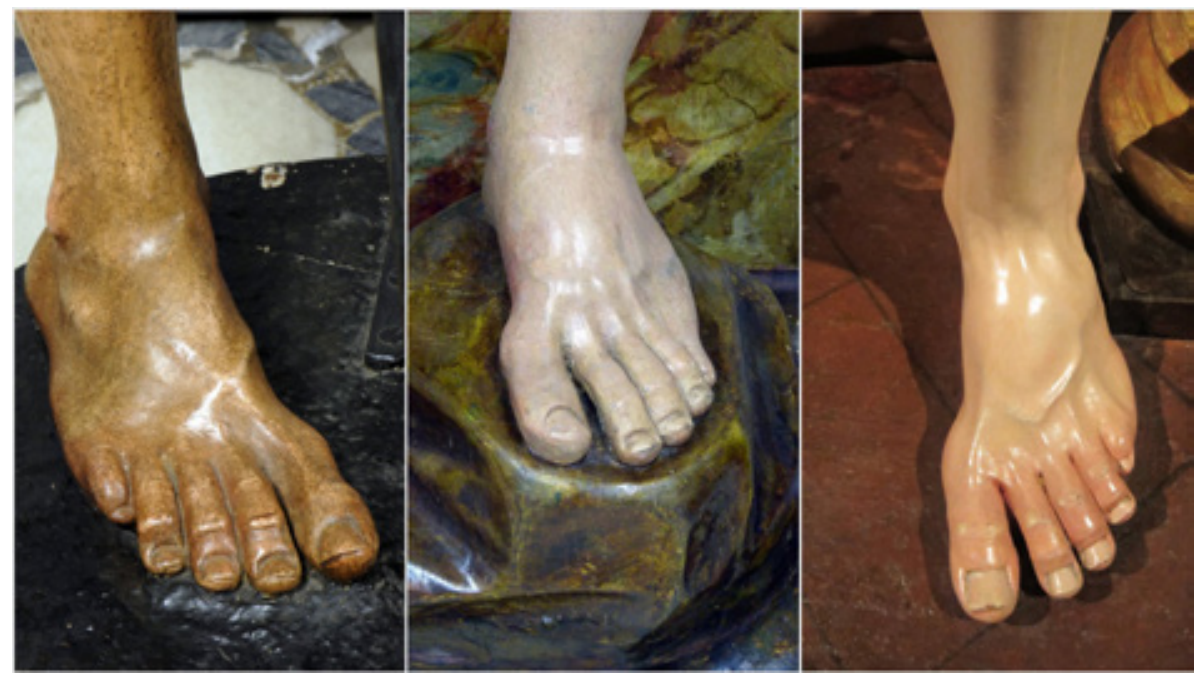

Figura 6. Benito de Hita y Castillo, Pies del San Juan Evangelista de la Hermandad de la Amargura de Sevilla, del Cristo de la Humildad y Paciencia de La Campana y de Nuestro Padre Jesús atado a la columna de Utrera. 